\title{
Gated myocardial SPECT imaging; true additional value in AMI?
}

\author{
E. E. van der Wall • A. J. Scholte $\cdot$ J. J. Bax
}

Received: 26 May 2010/Accepted: 27 May 2010/Published online: 8 June 2010

(C) The Author(s) 2010. This article is published with open access at Springerlink.com

Over the years, myocardial perfusion imaging has shown to be a very accurate approach in establishing the diagnosis myocardial ischemia and infarction [1-15]. It also allows identifying the site, size and the severity of perfusion defects in patients with acute chest pain. It is well known that perfusion abnormalities may persist for several hours after the acute event together with wall motion and wall thickening abnormalities very likely due to myocardial stunning. Analysis by gated SPECT imaging may detect these high risk patients who might otherwise be seen as low risk patients due to normal perfusion. This is particularly important in patients with inferolateral ischemia as perfusion artifacts are common in the inferolateral myocardial region [16-31]. Concentration and proximity of subdiaphragmatic radioactivity relative to myocardium comprise a major factor in the nature and severity of inferior wall artifacts. If the subdiaphragmatic radioisotope concentration is equivalent to that in the myocardium, complex, potentially uninterpretable hot and cold inferior wall artifacts are produced. Gating offers considerable additional value to SPECT myocardial perfusion

Editorial comment to the article of Neill et al. (doi: 10.1007/s10554-010-9641-0).

E. E. van der Wall $(\bowtie)$ · A. J. Scholte · J. J. Bax Department of Cardiology, Leiden University Medical Center, P.O. Box 9600, Leiden, Netherlands e-mail: e.e.van_der_wall@lumc.nl imaging in characterizing fixed defects thereby potentially improving test specificity. Since perfusion, function and wall motion/thickening can be assessed simultaneously, gated SPECT imaging follows the concept of a one-stop shop such as propagated by MRI studies [15, 32-45]. This holds in particular for regions with diminished radioisotope uptake. In case of preserved wall motion and/or thickening in region with a perfusion defect there might be still remaining viability influencing the appropriate management strategy [46-50]. On the other hand, it might be very interesting to study wall motion/thickening in areas with apparent normal myocardial perfusion in the acute phase of myocardial ischemia.

In the current issue of the International Journal of Cardiovascular Imaging, Neill et al. [51] used gated SPECT imaging at rest to compared semi-quantitative visual scores of perfusion, motion and thickening with an automated hypoperfusion index in patients with suspected acute inferolateral perfusion defects. In the absence of perfusion defects motion and thickening abnormalities were assessed. The authors studied 68 patients (of whom 56 with acute myocardial infarction) with chest pain at rest with either ST depression $\geq 0.1 \mathrm{mV}$ in $\geq 1$ of leads I, aVL, V1-V6 on 12-lead ECG or ST elevation $\geq 0.05 \mathrm{mV}$ in $\geq 1$ posterior lead on the body surface map. A rest gated SPECT image was performed within $24 \mathrm{~h}$ of the origin of chest symptoms. The ECG gated images were obtained 45-60 min after intravenous administration of 
350-400 MBq of Tc99-sestamibi. The myocardial images were semi-quantitatively evaluated for perfusion, motion and thickening. The scores were compared to the automated global hypoperfusion index. This index is equivalent to the product of the surface of the hypoperfused area and the mean severity of the hypoperfused area, and expressed as a percentage of the left ventricular mass. A hypoperfusion index $>5$ was considered abnormal. It was shown by the authors that the summed perfusion score correlated well with the hypoperfusion index. Summed thickening score correlated well with the hypoperfusion index and the agreement between the scorers was good. Of the 1,156 evaluated segments, $21 \%$ of normally perfused segments had a motion abnormality and $19 \%$ of normally perfused segments had a thickening abnormality. It was concluded that, using gated SPECT imaging, assessment of wall motion and thickening in addition to perfusion in acute myocardial ischemia improves the diagnostic accuracy for acute myocardial infarction in particular in patients with inferolateral wall ischemia.

Analysis of gated SPECT images for wall motion and thickening abnormalities adds important diagnostic and prognostic information to the assessment of myocardial perfusion. Using gated SPECT imaging, myocardial areas may be identified by the presence of wall motion or thickening abnormalities in the presence of normal perfusion. Wall motion and thickening defects are often present in a segment with abnormal perfusion and are useful for discerning real perfusion defects from artifacts. Occurrence of attenuation artifacts during non-gated SPECT perfusion imaging has been considered an important limitation of the technique [52-55]. Apical thinning due to the overlying diaphragm and the occurrence of anteroseptal defects as a result of breast attenuation are very common causes for unwanted perfusion deficits, leading to image misinterpretation and potentially a wrong diagnosis. In radionuclide myocardial perfusion SPECT imaging, successful attenuation correction programs have been developed in order to discriminate between true and false perfusion defects [56-58]. Nowadays, gated SPECT fulfills a pivotal role in discriminating true perfusion defects from artifacts. On the other hand, wall motion and/or thickening disturbances in normally perfused areas may unravel pathophysiological states such as myocardial stunning. Such a gated approach should be routinely used in evaluating myocardial SPECT images and this is validly underscored by the study of Neill et al. [51].

Open Access This article is distributed under the terms of the Creative Commons Attribution Noncommercial License which permits any noncommercial use, distribution, and reproduction in any medium, provided the original author(s) and source are credited.

\section{References}

1. Bavelaar-Croon CD, Pauwels EK, van der Wall EE (2001) Gated single-photon emission computed tomographic myocardial imaging: a new tool in clinical cardiology. Am Heart J 141:383-390

2. Bax JJ, Lamb H, Dibbets P, Pelikan H et al (2000) Comparison of gated single-photon emission computed tomography with magnetic resonance imaging for evaluation of left ventricular function in ischemic cardiomyopathy. Am J Cardiol 86:1299-1305

3. Chamuleau SA, van Eck-Smit BL, Meuwissen Met al (2007) Long-term prognostic value of CFVR and FFR versus perfusion scintigraphy in patients with multivessel disease. Neth Heart J 15:369-374

4. Tio RA, Slart RH, de Boer RA et al (2009) Reduced regional myocardial perfusion reserve is associated with impaired contractile performance in idiopathic dilated cardiomyopathy. Neth Heart J 17:470-474

5. Knaapen P, de Haan S, Hoekstra OS et al (2010) Cardiac PET-CT: advanced hybrid imaging for the detection of coronary artery disease. Neth Heart J 18:90-98

6. van der Wall EE, Heidendal GA, den Hollander W, Westera G, Roos JP (1980) I-123 labeled hexadecenoic acid in comparison with thallium-201 for myocardial imaging in coronary heart disease. A preliminary study. Eur J Nucl Med 5:401-405

7. Molhoek SG, Bax JJ, Bleeker GB et al (2004) Comparison of response to cardiac resynchronization therapy in patients with sinus rhythm versus chronic atrial fibrillation. Am J Cardiol 94:1506-1509

8. Thygesen K, Alpert JS, White HD (2007) Universal definition of myocardial infarction; joint ESC/ACCF/AHA/ WHF task force for the redefinition of myocardial infarction. Eur Heart J 28:2525-2538

9. van Lennep JE, Westerveld HT, van Lennep HW, Zwinderman AH, Erkelens DW, van der Wall EE (2000) Apolipoprotein concentrations during treatment and recurrent coronary artery disease events. Arterioscler Thromb Vasc Biol 20:2408-2413

10. Bavelaar-Croon CD, Kayser HW, van der Wall EE et al (2000) Left ventricular function: correlation of quantitative gated SPECT and MR imaging over a wide range of values. Radiology 217:572-575

11. van der Wall EE, van Dijkman PR, de Roos A et al (1990) Diagnostic significance of gadolinium-DTPA (diethylenetriamine penta-acetic acid) enhanced magnetic resonance imaging in thrombolytic treatment for acute myocardial 
infarction: its potential in assessing reperfusion. Br Heart $\mathrm{J}$ 63:12-17

12. van Dijkman PR, van der Wall EE, de Roos A et al (1991) Acute, subacute, and chronic myocardial infarction: quantitative analysis of gadolinium-enhanced MR images. Radiology 180:147-151

13. Braun S, van der Wall EE, Emanuelsson S, Kobrin I (1996) Effects of a new calcium antagonist, mibefradil (Ro 405967), on silent ischemia in patients with stable chronic angina pectoris: a multicenter placebo-controlled study. The mibefradil international study group. J Am Coll Cardiol 27:317-322

14. ten Kate GJ, Wuestink AC, de Feyter PJ (2008) Coronary artery anomalies detected by MSCT-angiography in the adult. Neth Heart J 16:369-375

15. Bakx AL, van der Wall EE, Braun S, Emanuelsson H, Bruschke AV, Kobrin I (1995) Effects of the new calcium antagonist mibefradil (Ro 40-5967) on exercise duration in patients with chronic stable angina pectoris: a multicenter, placebo-controlled study. Ro 40-5967 International Study Group. Am Heart J 130:748-757

16. Kurvers MJ, Braam RL, Verzijlbergen JF, Heestermans AA, Ten Berg JM (2007) Myocardial salvage in STEMI patients treated with primary coronary angioplasty as demonstrated by myocardial SPECT. Neth Heart J 15: 422-423

17. Jongbloed MR, Lamb HJ, Bax JJ et al (2005) Noninvasive visualization of the cardiac venous system using multislice computed tomography. J Am Coll Cardiol 45:749-753

18. de Nooijer R, Verkleij CJ, von der Thüsen JH et al (2006) Lesional overexpression of matrix metalloproteinase-9 promotes intraplaque hemorrhage in advanced lesions but not at earlier stages of atherogenesis. Arterioscler Thromb Vasc Biol 26:340-346

19. Hoogendoorn LI, Pattynama PM, Buis B, van der Geest RJ, van der Wall EE, de Roos A (1995) Noninvasive evaluation of aortocoronary bypass grafts with magnetic resonance flow mapping. Am J Cardiol 75:845-848

20. van der Laarse A, Kerkhof PL, Vermeer F et al (1988) Relation between infarct size and left ventricular performance assessed in patients with first acute myocardial infarction randomized to intracoronary thrombolytic therapy or to conventional treatment. Am J Cardiol 61:1-7

21. van der Wall EE, den Hollander W, Heidendal GA, Westera G, Majid PA, Roos JP (1981) Dynamic myocardial scintigraphy with $123 \mathrm{I}$-labeled free fatty acids in patients with myocardial infarction. Eur J Nucl Med 6:383-389

22. Vliegen HW, Doornbos J, de Roos A, Jukema JW, Bekedam MA, van der Wall EE (1997) Value of fast gradient echo magnetic resonance angiography as an adjunct to coronary arteriography in detecting and confirming the course of clinically significant coronary artery anomalies. Am J Cardiol 79:773-776

23. van der Hoeven BL, Pires NM, Warda HM et al (2005) Drug-eluting stents: results, promises and problems. Int $\mathbf{J}$ Cardiol 99:9-17

24. Ertaş G, van Beusekom HM, van der Giessen WJ (2009) Late stent thrombosis, endothelialisation and drug-eluting stents. Neth Heart J 17:177-180

25. Pluim BM, Lamb HJ, Kayser HW et al (1998) Functional and metabolic evaluation of the athlete's heart by magnetic resonance imaging and dobutamine stress magnetic resonance spectroscopy. Circulation 97:666-672

26. Scholte AJ, Schuijf JD, Kharagjitsingh AV et al (2008) Different manifestations of coronary artery disease by stress SPECT myocardial perfusion imaging, coronary calcium scoring, and multislice CT coronary angiography in asymptomatic patients with type 2 diabetes mellitus. J Nucl Cardiol 15:503-509

27. Torn M, Bollen WL, van der Meer FJ, van der Wall EE, Rosendaal FR (2005) Risks of oral anticoagulant therapy with increasing age. Arch Intern Med 165:1527-1532

28. Ypenburg C, Schalij MJ, Bleeker GB et al (2007) Impact of viability and scar tissue on response to cardiac resynchronization therapy in ischaemic heart failure patients. Eur Heart J 28:33-41

29. Ypenburg C, Roes SD, Bleeker GB et al (2007) Effect of total scar burden on contrast-enhanced magnetic resonance imaging on response to cardiac resynchronization therapy. Am J Cardiol 99:657-660

30. de Roos A, Matheijssen NA, Doornbos J et al (1990) Myocardial infarct size after reperfusion therapy: assessment with Gd-DTPA-enhanced MR imaging. Radiology 176:517-521

31. de Roos A, Matheijssen NA, Doornbos J, van Dijkman PR, van Rugge PR, van der Wall EE (1991) Myocardial infarct sizing and assessment of reperfusion by magnetic resonance imaging: a review. Int J Card Imaging 7:133-138

32. van Rugge FP, van der Wall EE, van Dijkman PR, Louwerenburg HW, de Roos A, Bruschke AV (1992) Usefulness of ultrafast magnetic resonance imaging in healed myocardial infarction. Am J Cardiol 70:1233-1237

33. Holman ER, van Jonbergen HP, van Dijkman PR, van der Laarse A, de Roos A, van der Wall EE (1993) Comparison of magnetic resonance imaging studies with enzymatic indexes of myocardial necrosis for quantification of myocardial infarct size. Am J Cardiol 71:1036-1040

34. Bleeker GB, Schalij MJ, Boersma E et al (2007) Relative merits of M-mode echocardiography and tissue Doppler imaging for prediction of response to cardiac resynchronization therapy in patients with heart failure secondary to ischemic or idiopathic dilated cardiomyopathy. Am J Cardiol 99:68-74

35. Ypenburg C, Sieders A, Bleeker GB et al (2007) Myocardial contractile reserve predicts improvement in left ventricular function after cardiac resynchronization therapy. Am Heart J 154:1160-1165

36. Ypenburg C, van der Wall EE, Schalij MJ, Bax JJ (2008) Imaging in cardiac resynchronisation therapy. Neth Heart $\mathbf{J}$ 16:S36-S40

37. van der Geest RJ, Niezen RA, van der Wall EE, de Roos A, Reiber JH (1998) Automated measurement of volume flow in the ascending aorta using MR velocity maps: evaluation of inter- and intraobserver variability in healthy volunteers. J Comput Assist Tomogr 22:904-911

38. Tops LF, Schalij MJ, Holman ER, van Erven L, van der Wall EE, Bax JJ (2006) Right ventricular pacing can induce ventricular dyssynchrony in patients with atrial fibrillation after atrioventricular node ablation. J Am Coll Cardiol 48:1642-1648

39. Bleeker GB, Holman ER, Steendijk P et al (2006) Cardiac resynchronization therapy in patients with a narrow QRS complex. J Am Coll Cardiol 48:2243-2250 
40. Bleeker GB, Bax JJ, Fung JW et al (2006) Clinical versus echocardiographic parameters to assess response to cardiac resynchronization therapy. Am J Cardiol 97:260-263

41. van Rugge FP, Boreel JJ, van der Wall EE et al (1991) Cardiac first-pass and myocardial perfusion in normal subjects assessed by sub-second Gd-DTPA enhanced MR imaging. J Comput Assist Tomogr 15:959-965

42. van der Wall EE, Vliegen HW, de Roos A, Bruschke AV (1995) Magnetic resonance imaging in coronary artery disease. Circulation 92:2723-2739

43. Oemrawsingh PV, Mintz GS, Schalij MJ, Zwinderman AH, Jukema JW, van der Wall EE (2003) Intravascular ultrasound guidance improves angiographic and clinical outcome of stent implantation for long coronary artery stenoses: final results of a randomized comparison with angiographic guidance (TULIP Study). Circulation 107:62-67

44. Portegies MC, Schmitt R, Kraaij CJ et al (1991) Lack of negative inotropic effects of the new calcium antagonist Ro 40-5967 in patients with stable angina pectoris. J Cardiovasc Pharmacol 18:746-751

45. Tops LF, Bax JJ, Zeppenfeld K et al (2005) Fusion of multislice computed tomography imaging with three-dimensional electroanatomic mapping to guide radiofrequency catheter ablation procedures. Heart Rhythm 2:1076-1081

46. America YG, Bax JJ, Boersma E, Stokkel M, van der Wall EE (2009) The additive prognostic value of perfusion and functional data assessed by quantitative gated SPECT in women. J Nucl Cardiol 16:10-19

47. van der Wall EE, Bax JJ, Jukema JW, Schalij MJ (2009) Gated SPECT in left bundle branch block: from improved diagnosis to improved treatment. Int $\mathbf{J}$ Cardiovasc Imaging 25:53-55

48. Bavelaar-Croon CD, Atsma DE, van der Wall EE, DibbetsSchneider P, Zwinderman AH, Pauwels EK (2001) The additive value of gated SPET myocardial perfusion imaging in patients with known and suspected coronary artery disease. Nucl Med Commun 22:45-55

49. Pitman AG, Kalff V, Van Every B, Risa B, Barnden LR, Kelly MJ (2005) Contributions of subdiaphragmatic activity, attenuation, and diaphragmatic motion to inferior wall artifact in attenuation-corrected Tc-99m myocardial perfusion SPECT. J Nucl Cardiol 12:401-409

50. Slart RH, Bax JJ, van Veldhuisen DJ, van der Wall EE, Dierckx RA, Jager PL (2006) Imaging techniques in nuclear cardiology for the assessment of myocardial viability. Int J Cardiovasc Imaging 22:63-80

51. Neill J, Harbinson M, Adgey J (2010) Myocardial wall motion and thickening assessment in early gated SPECT images of acute coronary syndrome patients likely to have inferolateral perfusion defects. Int J Cardiovasc Imaging. doi:10.1007/s10554-010-9641-0

52. Morita K, Tsukamoto E, Tamaki N (2002) PerfusionBMIPP mismatch: specific finding or artifact? Int J Cardiovasc Imaging 18:279-282

53. America YG, Bax JJ, Dibbets-Schneider P, Pauwels EK, Van der Wall EE (2005) Evaluation of the Quantitative Gated SPECT (QGS) software program in the presence of large perfusion defects. Int $\mathrm{J}$ Cardiovasc Imaging 21: 519-529

54. Purser NJ, Armstrong IS, Williams HA, Tonge CM, Lawson RS (2008) Apical thinning: real or artefact? Nucl Med Commun 29:382-389

55. Stinis CT, Lizotte PE, Movahed MR (2006) Impaired myocardial SPECT imaging secondary to silicon- and saline-containing breast implants. Int J Cardiovasc Imaging 22:449-455

56. Verburg FA, Romijn RL, Nekolla S, Verzijlbergen JF (2009) A phantom assessment of cold stomach-related artifacts in myocardial perfusion imaging. Nucl Med Commun 30:569-573

57. Kovalski G, Keidar Z, Frenkel A, Israel O, Azhari H (2009) Correction for respiration artefacts in myocardial perfusion SPECT is more effective when reconstructions supporting collimator detector response compensation are applied. J Nucl Cardiol 16:949-955

58. Ali I, Ruddy TD, Almgrahi A, Anstett FG, Wells RG (2009) Half-time SPECT myocardial perfusion imaging with attenuation correction. J Nucl Med 50:554-562 